\title{
MANTLE XENOLITHS FROM THE PRAIRIE CREEK LAMPROITE PROVINCE, ARKANSAS, USA
}

\author{
Dennis Dunn ${ }^{1}$, Douglas Smith ${ }^{1}$ and Steven C. Bergman ${ }^{2}$ \\ ${ }^{1}$ University of Texas at Austin, USA $;{ }^{2}$ University of Texas at Dallas, USA
}

\section{INTRODUCTION}

Mantle xenoliths have been recovered from diamondbearing olivine lamproite at the Black Lick and Twin Knobs satellite pipes in southwestern Arkansas. The xenoliths are small $(1-3 \mathrm{~cm})$ fragments of rock crushed during the evaluation of the diamond contents of the lamproites. The mantle xenolith suite includes the following rock types with approximate proportion: dunite (20\%), harzburgite, $(10 \%)$, wehrlite $(5 \%)$, eclogite $(10 \%)$, spinel lherzolite (30\%), garnet/spinel lherzolite $(10 \%)$ and garnet lherzolite $(15 \%)$. Minerals in 34 peridotite xenoliths have been analyzed by electron probe and used to calculate pressure-temperature arrays. All pressures and temperatures were calculated with the FORTRAN program TP01.v1 which is available on the web from www.geo.utexas.edu/DougSmith/.

\section{P-T CALCUlations}

Three garnet lherzolite xenoliths (bl4f, $\mathrm{m} 7$ and $\mathrm{m} 45$ ) record pressures of $\sim 4 \mathrm{GPa}$ and temperatures in excess of $900^{\circ} \mathrm{C}$. Three garnet lherzolite xenoliths $(\mathrm{m} 34, \mathrm{~m} 48$ and m49) record pressures of $\sim 3 \mathrm{GPa}$ and temperatures near $800^{\circ} \mathrm{C}$. Five additional xenoliths $(\mathrm{m} 22, \mathrm{~m} 25, \mathrm{~m} 27, \mathrm{~m} 31$ and $\mathrm{m} 35$ ) record pressures of $\sim 2.5 \mathrm{GPa}$ and temperatures less than $800^{\circ} \mathrm{C}$. Four of these seven xenoliths contain coexisting spinel and garnet and help to define the garnet/spinel transition zone within the upper mantle. The two P-T points for garnet websterite plot at relatively low pressure and high temperature well off the main trend. Calculated P-T conditions for xenoliths with garnet and orthopyroxene are in Table 1 and in Figure 1. The presence of garnet rims as overgrowths on spinel within four of the xenoliths confirm that the garnet-spinel transition zone occurs at pressures between 2 and $3 \mathrm{GPa}$.

\section{DISCUSSION OF RESULTS}

The P-T arrays calculated for the hottest $\left(>900^{\circ} \mathrm{C}\right)$ Arkansas mantle xenoliths are proposed to represent equilibration to a conductive, steady state geotherm at the time of lamproite eruption (excepting two anomalous garnet websterites). In order to compare the Arkansas geotherm with those elsewhere, the calculated $40 \mathrm{~mW} / \mathrm{m}^{2}$ geotherm of Pollack and Chapman (1977) and the xenolith-derived Kalahari (southern Africa) craton geotherm (Rudnick and Nyblade, 1999) are also shown in the P-T arrays (Figure 1). The Arkansas data at pressures of greater than $3.5 \mathrm{GPa}$ plot near a relatively cool mantle geotherm of $\sim 40 \mathrm{~mW} / \mathrm{m}^{2}$. This result is in agreement with calculations of temperature, based on $\mathrm{T}_{\mathrm{Ni}}$ in garnet, from $\sim 100$ garnets recovered at the Prairie Creek and Twin Knobs 1 lamproites which are consistent with a geotherm of $\sim 40 \mathrm{~mW} / \mathrm{m}^{2}$ (Griffin and others, 1994).

The two points representing garnet websterite fall well off the main P-T array, and these rocks may have formed later that the other peridotites. Calculated pressures are generally less than $2 \mathrm{GPa}$ and temperatures in excess of $1000^{\circ} \mathrm{C}$. These conditions are more representative of basaltic magma crystallization at depth and may have formed during underplating of basaltic magmas near the base of the continental crust.

Xenoliths from Archean cratons commonly have yielded P-T xenolith arrays corresponding to geotherms of $\sim 40 \mathrm{~mW} / \mathrm{m}^{2}$ or less. O'Reilly and others (2001) have used the observation that Archons (Archean cratons) typically record a geotherm cooler than $40 \mathrm{~mW} / \mathrm{m}^{2}$, wherea Protons (Proterozoic cratons) record geotherms of between 40-45 $\mathrm{mW} / \mathrm{m}^{2}$, and Tectons (cratons $<1 \mathrm{Ga}$ ) record geotherms of $50 \mathrm{~mW} / \mathrm{m}^{2}$ or more. This relationship was used by the authors to define a concept of technothermal age of the cratons which states that the older the craton, the cooler the associated geotherm. The Arkansas xenolith P-T array is similar to that of a stable craton of Early Proterozoic age or older.

Table 1: Selected Garnet Xenolith Data

$\begin{array}{cccc}\text { GPa } & \left({ }^{\circ} \mathrm{C}\right) & \text { olivine } & \text { garnet } \\ \text { PBKN } & \text { TBKN } & \text { Mg\# } & \text { Cr\# }\end{array}$

$\begin{array}{lrrrr}\text { Gt Lherzolite } & & & & \\ \text { b14f } & 4.6 & 977 & 92.4 & 13.3 \\ \text { m7 } & 3.9 & 930 & 92.3 & 25.0 \\ \text { m45 } & 3.6 & 936 & 92.4 & 20.1 \\ \text { m34 } & 3.1 & 767 & 92.2 & 8.8 \\ \text { m48 } & 3.2 & 869 & 90.8 & 4.6 \\ \text { m35 } & 2.6 & 759 & 90.8 & 4.5 \\ \text { m22 } & 2.1 & 757 & 90.1 & 3.6 \\ \text { Gt/Sp Lherzolite } & & & & \\ \text { m49 } & 3.1 & 835 & 90.5 & 3.0 \\ \text { m27 } & 2.2 & 805 & 90.2 & 3.4 \\ \text { m25 } & 2.5 & 784 & 90.5 & 2.9 \\ \text { m31 } & 1.9 & 585 & 90.8 & 2.6 \\ \text { Gt Websterite } & & & & \\ \text { m43 } & 2.2 & 1045 & \text { na } & 8.5 \\ \text { m42 } & 1.5 & 1186 & \text { na } & 8.5\end{array}$




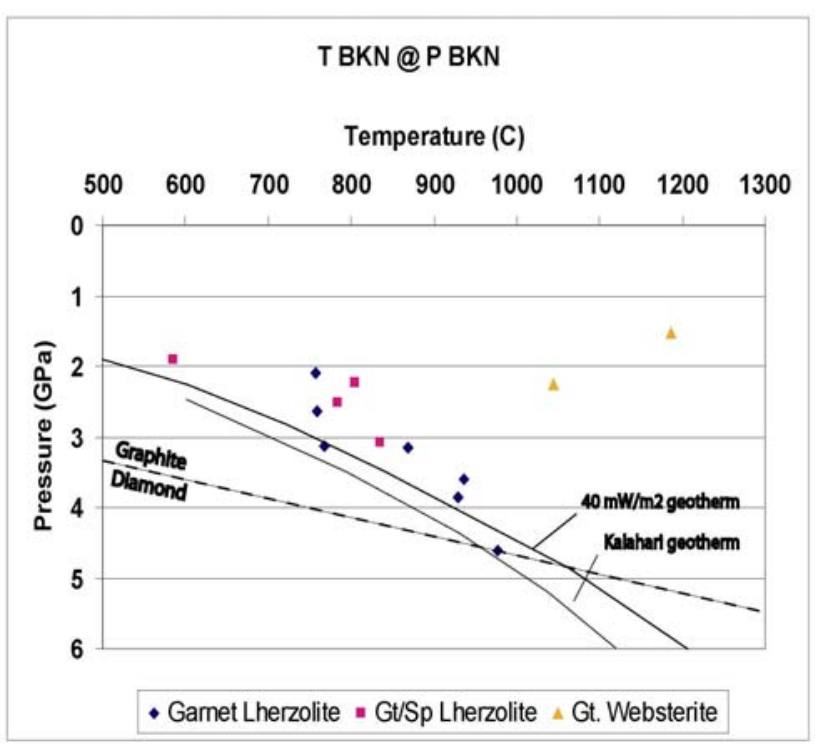

Figure 1: P-T xenoliths array utilizing T BKN @ P BKN (Brey and others, 1990). Note that the deep xenoliths plot close to the $40 \mathrm{~mW} / \mathrm{m}^{2}$ geotherm.

The forsterite content of olivine can be used as a proxy for the amount of melt depletion within the mantle. There is also a strong correlation between the average forsterite content in olivine and the age of the lithospheric mantle from which the olivine is derived (Gaul and others, 2000). These authors observe that Archean age mantle lithosphere olivine is $\sim \mathrm{Fo}_{92-93}$, Proterozoic lithosphere olivine is $\sim \mathrm{Fo}_{91-92}$ whereas Phanerozoic mantle lithosphere olivine is $\sim \mathrm{Fo}_{90}$. A comparison of the forsterite content of olivine vs. calculated pressures (depth) for the xenoliths yields estimated mantle depletion with depth. Data for all xenoliths containing a geobarometer assemblage indicate a general trend of increasing mantle depletion with depth to pressures of $\sim 5 \mathrm{GPa}$.

Inclusion of the forsterite content of olivine within all spinel peridotites would add many more data points to this graph; however, spinel peridotites do not contain a reliable geobarometer. It is reasonable to assume that most typical (low-Cr) spinel peridotites have equilibrated at pressures of $\sim 1.5 \mathrm{GPa}$, a value which is less than the xenolith-defined spinel-garnet transition zone calculated at pressures between 2 and $3 \mathrm{GPa}$. Ten of the 17 spinel peridotites qualify as typical low-Cr spinel lherzolites and have forsterite contents of olivine between $\mathrm{Fo}_{89.5}$ and $\mathrm{Fo}_{91.2}$.

The other seven spinel peridotites are mid-Cr and high- $\mathrm{Cr}$ spinel peridotites (spinel with $>30$ wt $\% \mathrm{Cr}_{2} \mathrm{O}_{3}$ ) with olivine in the range of $\mathrm{Fo}_{91.4}$ to $\mathrm{Fo}_{93.5}$. The high-Cr spinel peridotites may represent a distinct group of mantle xenoliths. Boyd and others (1999) showed that spinel peridotites containing orthopyroxene with less than $1.0 \mathrm{wt}$ $\% \mathrm{Al}_{2} \mathrm{O}_{3}$ may represent peridotite equilibrated at pressures within the garnet stability field. Three high-Cr spinel peridotites all have less than 1.0 wt $\% \mathrm{Al}_{2} \mathrm{O}_{3}$ and a $\mathrm{Cr}-$ number in spinel of $\sim 70$. These three high-Cr xenoliths could represent "garnet-facies" spinel peridotite equilibrated at pressures substantially above 2-3 GPa and these are plotted at $3.5 \mathrm{GPa}$ in Figure 2.

The four mid-Cr spinel lherzolites are assumed to represent pressures of $\sim 2.5 \mathrm{GPa}$, midway between the two groups and well within the garnet/spinel transition zone as recorded by the four garnet/spinel lherzolites. Addition of all the spinel peridotites to the previous plot of garnet lherzolite depletion vs. depth indicates that the trend of increasing mantle depletion with depth is still observed (Figure 2). The division between relatively fertile shallow mantle $\left(<\mathrm{Fo}_{91.5}\right)$ and depleted deeper mantle $\left(>\mathrm{FO}_{92}\right)$ lithosphere occurs at pressures of $\sim 3 \mathrm{GPa}$.

A plot of xenolith abundance and mineralogy used in conjunction with estimated pressure of origin yields a theoretical depth profile of the sub-continental lithospheric mantle beneath southwestern Arkansas at the time of eruption (Figure 3). The deepest part of the section is dominated by relatively depleted high-Cr spinel harzburgite and high-Cr garnet lherzolite, whereas the uppermost mantle section consists of relatively fertile low-Cr spinel lherzolites and a higher abundance of eclogite, wehrlite and garnet websterite.

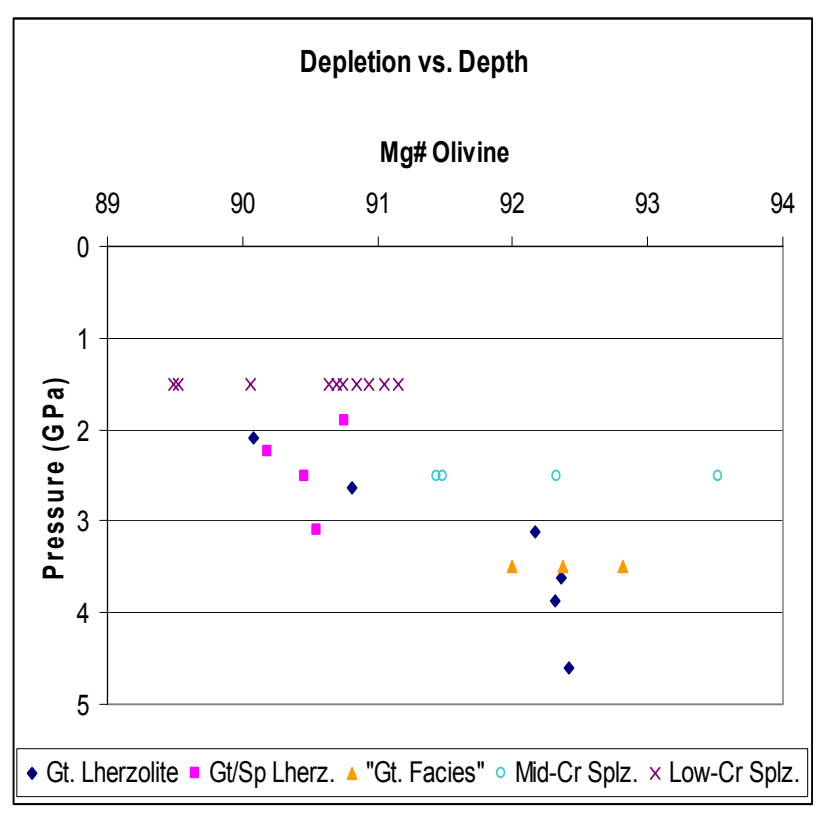

Figure 2: Comparison of forsterite content of olivine with calculated and assumed pressure. Increasing Mg-number correlates with increasing pressure. 


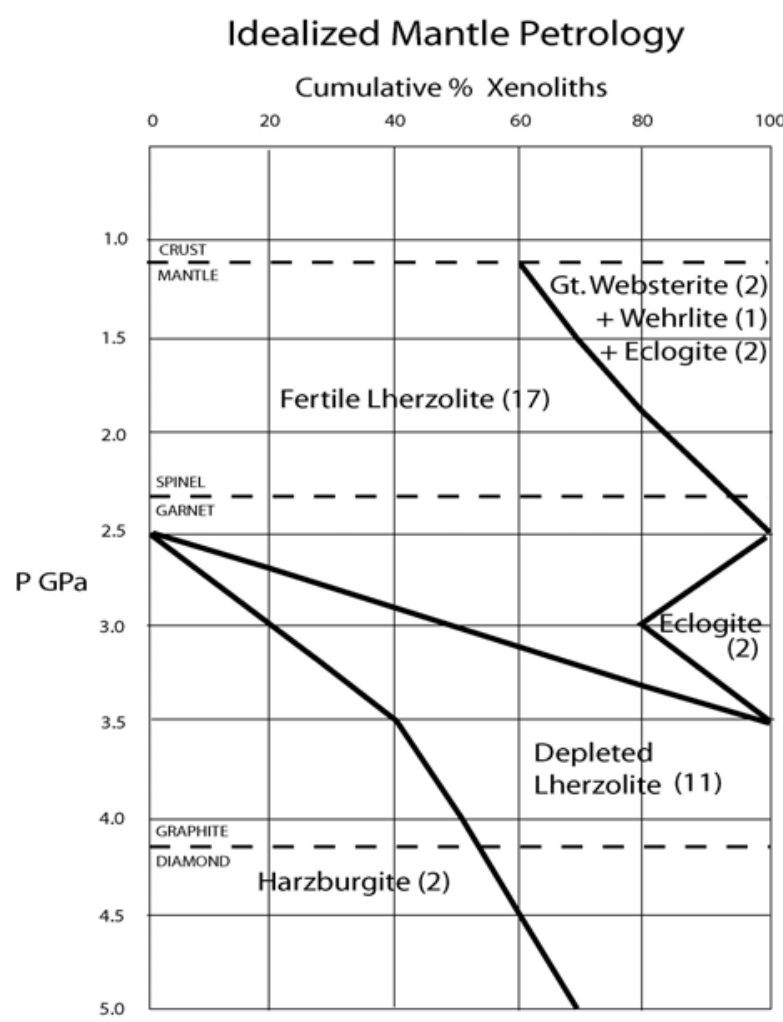

Figure 3: Idealized section of mantle lithosphere beneath the Prairie Creek lamproite province. Xenolith amount shown in parenthesis.

The finding of fertile mantle lithosphere overlying depleted mantle lithosphere is consistent with two possible emplacement scenarios. The first proposed model is that an allochthonous terrane of either Archean or Early Proterozoic age was incorporated into the southern margin of the North American craton before the development of the mid-continent granite-rhyolite terrane. Evidence that is consistent with such a scenario is $\mathrm{U}-\mathrm{Pb}$ dating of one zircon recovered from concentrates from the Prairie Creek lamproite that records a $1.85 \mathrm{Ga}$ isotopic age, older than any known crustal rocks in the region (Reichenback and Parrish, 1988). Also, Nelson and DePaolo (1985) have determined Sm-Nd crustal formation ages for several clustered samples from the granite-rhyolite terrane in southern Oklahoma to be from 1.81 to $1.98 \mathrm{Ga}$ in age. It is possible that these $\sim 1.9 \mathrm{Ga}$ ages could represent a sample of preserved allochthonous terrane.

A second model for the presence of the two layer mantle lithosphere involves tectonic emplacement of relatively old depleted mantle lithosphere beneath younger (Upper Proterozoic) more fertile continental lithosphere by subduction within a large scale continent-continent collision. Dalziel and others (2000) proposed that the continent-continent collision which generated Grenville deformation resulted from collision of the southern margin of the North American craton with the Kalahari craton. Preservation of part of this Archean craton may have occurred due to tectonic stacking of depleted mantle lithosphere which might preserve an Archean lithosphere keel, as suggested for other regions by Poudjom Djormani and others (2001).

Evidence for possible juxtaposition of mantle lithosphere comes from isotope studies. Lambert and others (1995) have used Re-Os isotopic studies of the Prairie Creek lamproite to obtain a lithosphere separation model age of $\sim 1.2 \mathrm{Ga}$. However, they suggest that subduction-related processes associated with Grenville-Llano tectonics may have juxtaposed allochthonous mantle lithosphere under the Middle Proterozoic age craton. Alibert and Albarede (1988) used $\mathrm{Sr}, \mathrm{Nd}$ and $\mathrm{Pb}$ isotope data to infer that the Prairie Creek lamproite shows a major contribution of ancient recycled sediments in its mantle source in contrast to North American "kimberlites".

Arkansas mantle xenoliths reveal the existence of a shallow fertile mantle layer above a depleted mantle layer, with a relatively sharp contact between them. This juxtaposition of sub-continental mantle lithosphere suggests a two-stage construction of the sub-continental mantle lithosphere beneath southwestern Arkansas. It is proposed that this juxtaposition was tectonically emplaced either by incorporation of an older allochtonous terrane within the southern margin of the North American craton or by tectonic stacking of sub-continental mantle lithosphere during a continent-continent collision. A similar tectonic emplacement scenario might be applicable to other areas with comparable structured subcontinental lithospheric sections.

\section{REFERENCES}

Alibert, C. and Albarede, F., 1988. Relationship between mineralogical, chemical and isotopic properties of some North American kimberlites: Journal of Geophysical Research, v. 93, no. b7, p. 7643-7671.

Boyd, F.R., D.G. Pearson, and Mertzman, S.A., 1999. Spinelfacies Peridotities from the Kaapvaal Root: in Fei, Y. et al., eds., Mantle Petrology: Field Observations and High Pressure Experimentations: The Geochemical Society, Special Publication No. 6. p. 40-48.

Brey, G.P., Kohler, T., and Nichol, K.G., 1990. Geothermobarometry in four phase lherzolites I: experimental results from 10 to $60 \mathrm{~kb}$ : Journal of Petrology, v.31, p.1313-1352.

Dalziel, I.W.D., Mosher, S. and Gahagan, L.M. 2000. Laurentia-Kalahari collision and the assembly of Rodinia: Journal of Geology, v. 108, p.499-513. 
Dunn, D., 2002. Xenolith mineralogy and geology of the Prairie Creek lamproite province, Arkansas: Ph.D. dissertation, Univ. of Texas at Austin, Austin, TX, 147 pp.

Gaul, O.F., Griffin, W.L., O'Reilly, S.Y. and Pearson, N.J., 2000. Mapping olivine composition in the lithospheric mantle: Earth and Planetary Science Letters, v. 182, p. 223-235.

Griffin, W.L., O'Reilly, S.Y., Ryan, C.G. and Waldman, M.A., 1994. Indicator minerals from Prairie Creek and Twin Knobs lamproites: Relation to diamond grade: in Proceedings of the Fifth International Kimberlite Conference, CPRM Special Publication, v. 2, p. 302-311.

Lambert, D.D., Shirey, S.B. and Bergman, S.C., 1995. Proterozoic lithospheric mantle source for the Prairie Creek lamproites: $\mathrm{Re}-\mathrm{Os}$ and $\mathrm{Sm}-\mathrm{Nd}$ isotopic evidence: Geology, v. 23, no. 3, p. 273-276.

Nelson, B.K., and DePaola, D.J., 1985. Rapid Production of Continental Crust 1.7-1.9 b.y. ago: Nd isotopic evidence from the basement of the North American mid continent: Geological Society of America Bulletin, v. 96, p. 746754.

O'Reilly, S.Y., Griffin, W.L. Djomani, Y.H. and Morgan, P., 2001. Are lithospheres forever? Tracking changes in subcontinental lithospheric mantle through time. Geological Society of America Today, v. 11, no. 4, p. 410 .

Pollack, H.N. and Chapman, D.J., 1977. On the regional variation of heat flow, geotherms, and the thickness of the lithosphere. Tectonophysics, v. 38, p. 279-296.

Poudjom Djomani, Y.H., O'Reilly, S.Y., Griffin, W.L. and Morgan, P., 2001. The density structure of subcontinental lithosphere: Constraints on delamination models, Earth and Planetary Science Letters, v. 184, p. 605621 .

Reichenbach, I. and Parrish, R., 1988. Age of crystalline basement in BC and NWT, Canada, and $\mathrm{CO}$ and AR, U.S.A., as Inferred from U-Pb zircon geochronology of diatremes: Geological Society of America Abstracts with Programs, v. 20, p. A-110

Rudnick, R.L., and Nyblade, A.A., 1999 The thickness and heat production of Archean lithosphere: Constraints from xenolith thermobarometry and surface heat flow: in Fei, Y. et al., eds., Mantle Petrology: Field Observations and High Pressure Experimentations: The Geochemical Society, Special Publication No. 6. p. 3- 12.

Dennis P. Dunn

5802 Republic of Texas Blvd.

Austin, Texas 78735

dendunn@ix.netcom.com. 